\title{
開発地域の環境価值評価手法について
}

Summary of Valuation Methods for Environment subject to Development Pressure

阪東浩造* ·鈴木秀男**

Kozo Bando and Hideo Suzuki

Evaluation of values and functions of the area, which will be impacted by development, is a key to environmentally friendly practices in planning and design. This paper reviews the several assessment methods developed and used in the U.S., where more systematic environment protection scheme, including mitigation, is implemented. Each method differs in terms of area of interest, functions to be evaluated and evaluation process, but they have potential of evaluating Japanese wetlands especially if they are improved considering the characteristics observed in the Japanese coastal area.

Keywords : evaluation of values and functions, wetland, mitigation, habitat

1.はじめに

沿岸域における開発と環境保護をバランスさせ環境劣化を防ぐためには、十分な検討と柔軟な対応を要請する 制度の確立・対象域の価值評価ならびに開発による環境価値の減少評価・環境修復の技術などの要素が理解され 整備されることが重要である。また、価值評価においては、対象地域の様々な価值をできる限り客観的に評価す る道具があることが望ましい。流況、水質などの物理化学的な評価は、数值モデルによる解析技術が向上し、定量的な評価 が行えるようになってきているが、生物的な評価は、プランクトンのような低次の生物については数值モデルによりある程度の 精度で可能ではあるものの、直接的な影響を受けやすい生物や生態系の評価や機能を直接評価することは、かなり難しい。

米国では、湿地帯の機能や価値比較・詳細な調査実施のための判断資料・開発前後の機能と価值の比較・ミテ イゲーション制度によって修復あるいは創造された湿地帯と開発による影響を受ける前の湿地帯との比較・ミテ イゲーションバンクのクレジット評価などのために、水域地域を対象とし、生息する生物・地形・植生などを考 慮した様々な価值評価手法が開発されている。アメリカで開発された評価手法が、常にそのままの形で日本で用 いることができるかどうかは疑問であるが、その考え方を知ることや一部修正して用いることは十分可能である との判断から、これら評価法を整理することにした。

\section{2. 環境価値評価手法}

（1）評価手法の分類と概要

アメリカでは、主に湿地帯の価値を評価する方法として、幾つかの手法が開発され実際に適用されている。こ れらの評価手法には、大きく分けて、対象地域の単一の機能に着目する評価法と、いくつかの機能を評価項目と して対象地域全体の評価を行う評価法がある。前者は歴史が古く、一個の数字で価值が表現されることが多く、 簡略で使いやすい方法とされている。一方、後者は地域の多様な価値を評価できる長所がある一方、評価が定性 的となったり、複数の定量評価となるため、前者に比べ評価が複雑で実用上は使いづらくなる傾向がある。

当初は、評価項目を絞った評価法が開発された。1976 年には、今日用いられている多くの評価手法の出発点と なったHEPが、The Fish and Wildlife Serviceによって開発された。HEPでは、簡単な方法で定量評価を与える ため、比較的多くの適用例があり、ミティゲーション・バンクでも湿地帯間の比較を容易にするための様々な修 正を加えて採用されている。1980 年には、同様な考え方に基づく HES が US Army Corps of Engineersによって 開発された。この方法では評価種を選択するのではなく、生息地の地形について評価する手法で、特定種につい ての評価というよりは対象地域全体の生息地としての質を評価するものである。

その後、湿地帯の複雑さや多様な機能が認知されるようになり、広範囲な要素を評価する手法が現れた。このカ テゴリーに属する評価法として最初に開発されたのが WETである。WET は、主に湿地帯を対象として、1983 年に 第一版が発表され、1987 年には改良版が開発された。湿地帯を広範囲な観点から評価する手法として、多く用い られているほか、このカテゴリーに属する他の手法の開発に大きな影響を与えている。その一例が、精度の向上 と評価の数量化を目的とした HGM である。HGM は、湿地帯を地形形態・水理的特性などによって分類しているこ と、地域性を考慮していることなどが特徴となっている。

\footnotetext{
* 正会員 鹿島建設技術研究所第一研究部（１82 東京都調布市飛田給 2-19-1）

** 正会員 東亜建設工業土木本部技術開発部
} 
以上の評価手法は、米国の地形の特徵である湿地帯を対象としているが、最近では、少し水深の深い地点での 評価を行うための手法として、BRATやBEST が開発され一部適用されている。BEST は、食物源・避難場所・産卵 場所・稚魚の成育場所などの機能について評価する手法であり、さらに改良版を開発中である。

このような評価法とは別に、古くから用いられ現在でも多用されている方法が、専門家による判定である。対 象とする地域や水理および生態系に詳しい専門家を必要とし客観性に欠ける面もあるが、機械的な評価法では見 逃す恐れのある価值を常識的に評価できるという大きな利点も有している。ミティゲーションバンクでも、特に 小規模なサイトではこの評価法を採用するところが多い。湿地帯の修復においては、植生の密度・植物の種類 · 動物の種類と量など生物の種類や量で判断することも多い。また、生物の多様性については、地形的な多様性と 密接な関係があるため、湿地内の水路の密度や湿地帯の表面の高さなどを参考にしている。

このように、幾つかの評価法が開発され実際に適用されているが、どの評価方法も完璧とはいえず、価値を評 価する場合には、特徵のあるいくつかの評価法を組す,合わせて各々の欠点を補うことが精度面と将来の不確実性 を最小化する上で、一つの選択肢と考えられる。

（2）各評価手法の適用範囲

前節で説明したように、アメリカで開発された評価手法は、評価対象や歴史的な社会の要請の変化など から適用可能な地形は限定される。代表的な評価手法について、表一 1 にそれぞれの適用範囲を示す。こ の表から、HEP・HES は陸上から浅海域まで広範囲に適用できる手法で、特に、陸地での評価に適しており、 WET·HGM は湿地帯に限られた手法であることがわかる。一方、BRAT・BEST は海域に適応する手法である。

表 -1 評価手法の適用範囲

\begin{tabular}{|c|c|c|c|}
\hline 場所 機能 & $\begin{array}{l}\text { HES } \\
\text { HEP }\end{array}$ & $\begin{array}{l}\text { WET } \\
\text { HGM } \\
\end{array}$ & $\begin{array}{l}\text { BRAT } \\
\text { BEST }\end{array}$ \\
\hline Upland & (a) & $\bar{x}$ & $x$ \\
\hline Wetland & 0 & () & $x$ \\
\hline Subtidal shallow & $\Delta$ & $x$ & () \\
\hline Subtidal deep & $x$ & $x$ & () \\
\hline
\end{tabular}

【凡例】の：最適である ○：適用できる $\triangle ：$ 適用に問題がある $\times ：$ 適用できない

( 3 ) 各評価手法の特徴

(i) HEP (Habitat Evaluation Procedure)

この手法の特徵は、湿地带の機能として、生物に対する生息地としてのみの価偩を認め、選定した幾つか の生物種に焦点をあてて評価し、その結果を一つの数量で与えることである。評価を比較的簡単に、使い やすい一個の数字に集約できることから、実用上は多く用いられている。その反面、客観性に劣ることや、 種を独立した個体として取り扱うため、種の集団、すなわちエコシステム的な考察が欠けているとの指摘 もある。

HEP は、次のような手順で実施される。

(1)対象地域を決定する。

(2)対象地域を異なる地目（何で覆われているか）によって線引きし、小領域に分割する。

(3)評価種を選定する。評価種の選択は、その湿地帯で発見されるであろう種・社会的あるいは経済的な 価值の高い種・対象地域全域の生態系環境を代表すると考えられる種・特定の生物種の復活がプロジ エクトの目的がある場合その種・人為的な活動に敏感な種、などの条件を考慮しながら決定される。

(4)一つの小領域が、各評価種に対してどの程度の価值（HSI）があるかを、同じ地目で最適な条件を備 えている生息地に対する割合で計算する。計算された HSI にその小領域の面積を乗じて生息地単位 (HU) を計算する。HUを全ての小領域に対して加え合わせることにより、対象地域の生息地としての 評価が、一つの数量で計算される。

(ii) WET (Wetland Evaluation Technique)

WETによる評価は、湿地帯の複数の機能に注目することと、評価が定性的となっている点で、HEP と異な る。その概念は、以下に説明するようにより科学的で HEP の不備を補うものであるが、結果が 3 段階評価 (High・Moderate · Low) で与えられるので、実用上不便な面もある。

表一 2 は、WET で考慮されている 11 個の機能と価值を整理したものである。この他にも、水鳥・湿地带 に依存する鳥類・魚類・無脊椎動物などの生息地としての適正度を評価することができる。これら 11 個 
の機能は、社会的重要度・機能を有効に発揮する能力・機能を発揮する機会の観点から評価される。社会 的重要度は、ある機能が社会に対してどれだ忛重要な機能であるかを判定するもので、湿地帯の特別な存 在目的の有無・潜在的な経済価值・能力発揮の戦略的な位置にあるかどうかを考慮する。機能を発揮する 能力は、湿地帯がその機能を遂行できるが判定し、機能を発揮する機会は、湿地帯がその機能に対して 有効となり得る機会をもっているかどうかを判定する。

\begin{tabular}{|l|l|l|}
\multicolumn{2}{c|}{ 表一 2 WET で考慮される機能 } \\
\begin{tabular}{|l|l|l|}
\hline 地下水への水の供給 & 地下水からの水の補給 & 洪水調整 \\
\hline 侵食に対する地形安定化 & 土砂や有害物質の保留 & 栄養塩の除去と変態 \\
\hline 有機物（植物）の系外輸送 & 野生生物の多様性と多数性 & 水生生物の多様性と多数性 \\
\hline レクリエーション & 希少性/歴史的遺産価値 & \\
\hline
\end{tabular}
\end{tabular}

評価は次のように行われる。なお、干潟を対象とした具体的な評価例は、新保ら（1997）に見られる。 (1)評価を実施する観点によって、評価手順の内容が異なるため、評価する観点を選択する。

(2)各機能評価のレベルを、要求精度・収集可能資料・時間などに応じて選択する。

(3)各機能に対する評価は、数十個の質問に答えながら進められる。これらの質問は、湿地帯の水文学的 性質・水理的性質・地形・植生に関するものである。

(4)質問の答えを解析することにより各機能についての定性的評価が決定される。この解析は、技術的資 料による裏付けのある質問結果と各機能の関係（解釈キー）を用いて行われる。

WET を適用する時には、次のような事項に注意することが必要である。

(1) WET による定性的な評価は、ある機能あるいは価值がその湿地帯に存在したり発生したりする確率の 評価で、開発計画者に対して湿地帯がある機能を保持している可能性を警告することを目的とする。

(2) High・Moderate・Low の定性的評価は、質問に対する答えを解析する解釈キーに依存して決定される。 この解釈キーが、High あるいはLow の確率を結果として出すためには、科学的に明瞭な判定基準を満 たすことを要求するため、WETによる評価では Moderate という評価が与えられることが多い。

(3) WET は定性的な評価であり、この評価を数字で置き換えたり、これらを足しあわせて全体的な数量評 価を行うことは適切ではない。

(4)ミティゲーション制度の中での利用については、代償措置が必要かどうかについての判断に用いる べきではなく、代償措置が必要と既に決定されたプロジェクトに対して、正当なミティゲーションレ ベルについてーつの見通しを与えることォ゙Tの目的である。

(5) WET は、in-kind のミティゲーションの設計を行う時に有効である。これは、in-kind ミティゲーシ ヨンで対象とする湿地帯は、一般に、機能が同一であるといえるからである。

(i i i) HGM (Hydrogeomorphic Approach)

この評価手法は、WETによる評価のように湿地帯の多様な機能に注目しながら、その評価は数量化してお り、HEP と WET の特徵を取り入れた手法となっている。

さらに、新しい評価過程が採用され、次に示すように、変数への数值の割り当てに工夫がなされている。 これは、当該湿地帯の周辺に存在する最良の状態の湿地帯を標準湿地帯とし、評価すべき湿地帯をこの標 準湿地帯と対比することにより、より客観的で容易な評価を目指したものである。さらに、状態の悪い湿 地帯も参照值として評価しておけば、尺度はより完璧となり評価点を与えやすくなる。このように、HGM では、近隣地域の湿地帯を参考に比較の尺度を確立するため、地域性を考慮した評価となる。

評価では、まず、湿地帯を地形形態・水理的特徴などを参考に分類し、当該湿地带にあてはまる機能に ついて詳細に検討する。河川周辺の湿地帯の持つ機能としては、表一3のような機能が考えられている。

表一3 HGM で考慮される河川周辺の湿地帯の持つ機能

\begin{tabular}{|l|l|l|}
\hline 短期的な洪水水の保留 & 長期的な表面水の保留 & 水流エネルギーの低下 \\
\hline 地下水保留 & 地下水移動の緩和 & 栄養塩の変態 \\
\hline 流入栄養塩や污染物質の除去 & 粒物質の保留 & 有機炭素の流出 \\
\hline 植生の維持 & 枯草木の生産蓄積分散 & 生態系の空間構造維持 \\
\hline 水生生物の域外からのアクセス & 無脊椎動物の維持 & 脊椎動物の維持 \\
\hline
\end{tabular}


一つの機能に対しては、幾つかの変数がある。これらの変数に、確立された尺度と比較して $1 \sim 0$ の指標 を割り当てた後、機能と変数を結び付ける関係式に代入することにより、その機能に対する評価を行う。 たとえば、無機および有機物の滞留機能は、洪水頻度 $V_{\mathrm{freq}}$ 、陸上からの流入 $\mathrm{V}_{\mathrm{sur} \text { i in }}$ 、草の繁茂密度 $\mathrm{V}$ herb、低木量 $\mathrm{V}_{\mathrm{shrub}}$ 、木の根幹 $\mathrm{V}_{\mathrm{b} \mathrm{ree}}$ 、木の密度 $\mathrm{V}_{\mathrm{tree}}$ 、小さな凸凹 $\mathrm{V}_{\mathrm{micro}}$ 、落木 $\mathrm{V}_{\mathrm{cwd}}$ を変数として、 次式で評価される。

$$
\text { 評価 }=\left\{\left[\left(\mathrm{V}_{\text {FREQ }}+\mathrm{V}_{\text {SURPIN }}\right) / 2\right] \times\left[\left(\mathrm{V}_{\text {HRRB }}+\mathrm{V}_{\text {SHRUB }}+\mathrm{V}_{\text {BTREE }}+\mathrm{V}_{\text {DTREE }}+\mathrm{V}_{\text {HICRO }}+\mathrm{V}_{\text {CWD }}\right) / 6\right]\right\}^{1 / 2}
$$

(iv) BRAT(Benthic Resources Assessment Technique)

BRAT は、底生生物全種の生育量 - 分布状況や、魚類・鳥類によって摂饂される底生生物の生育量・分布 状況の調查から、対象海底の摂䭒供給価值や生物の利用価值を評価する手法であり、次に述べる BEST のも とになった評価手法である。この手法の特徴は、魚類や鳥類の摂䬱習慣、すなわち魚類の場合は優占種の 胃内容物、鳥類の場合はチドリ類の嘴の長さと形状から、餌となる底生生物量を調べて、対象となる場所 の価值を評価することにある。しかし、この方法は、他の方法よりも直接的に餌の供給価值や利用場所の 価值を評価できるが、資料分析は膨大な時間を消費し、結果の解釈は難しい。また、生態系の立場からは、 中層上層に住む魚の考慮も必要であること、海底が魚にとって餌を求める場所という一個の機能価値だけ を考える方法であるという欠点もある。この方法は、浚渫土砂の海洋投棄のモニタリングや、また公共水 域の海洋投棄場所の選定に利用されてきた。また、様々な食性を持つ生物群の HSI 值を測定することによ り HEP を兼ねることも可能となる (Lunz and Kendall、1982)。最近では、底生生物と沈殿物の分布を効果 的に描くリモートセンシング技術である SPI (沈殿物分類画像)と共用して、評価することがある。

(v) BEST(Biological Evaluation Standardized Technique)

BEST は、新たに創出する環境と、消失する沿岸域環境を考慮して、相対的な価值変化を定量的に評価す る方法である。評価対象海域、対象生物種、評価基準の 3 つの要素で、それらの相互関連性を三次元マト リックスで評価する方法であり、図ー1に概念モデルを示す。この方法は、現地観測データを使用するた め、定量的な評価ができるが、魚種の選 扒が絬果を大きく左右すると考えら北 ている。また BRAT と異なり、海底を食 物を得る機能の他に、避難場所・産卵場 所・稚魚の成育場所などの機能を考慮し ているため、人工魚礁にも適用できる。 この場合、漁獲量を増加させるという視 点ではなく、生態系への貢献という観点 から詊体することが目的である。

これまでに、カリフォルニア州海岸で 人為的な影響を受けていない漁礁の価 值と、ロサンジェルス港の人工漁礁と砂 地盤の生息地の価值を比較するために 用いられたり、カリフォルニア州アナハ イム湾の代替湿地の価值と人為的影響 を受けていない場所の比較に使われて

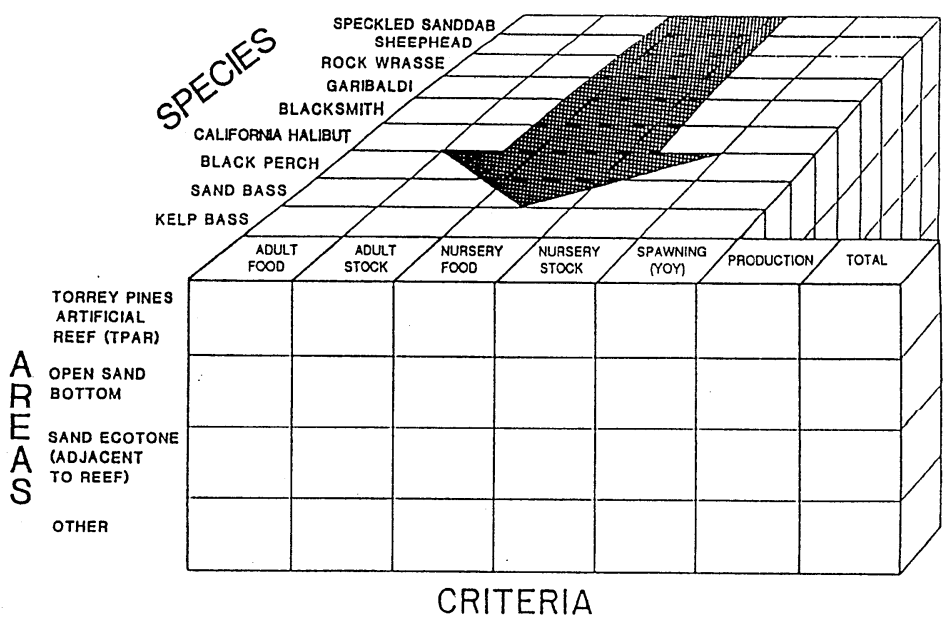

因 1 BESTによる評価概念図

(MEC Analytical Systems, Inc. (1991)加拔粋) きた。

この方法では、具体的には以下の手順にしたがって評価が進められる。

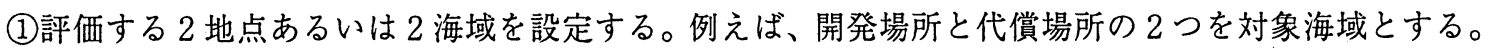
(2)魚種の重要度や生態学的な特性から見て、対象魚種を 10 種選定する。異なる魚種を対象とする場合 は、特性の等価な魚種で代行する。

(3)成魚の現存量、成魚の餌生物の現存量、稚魚の現存量、稚魚の餌生物の現存量、産卵量、生産量の評 価基準 6 項目について調査する。

(4)解析事例の一部を下記に示す。解析は、レベル 1 で対象海域の各魚種の調査データを評価基準毎に入 カし、レベル 2 で対象海域 2 地点の各評価值の和が 1 になるように換算し、最後にレベル 3 で各対 象海域の評価值を加算して合計点を求めて、相対評価を行う。なお、レベル 1 ・レベル 2 では各対 
象海域 1 魚種のみの值について例示し、レベル 3 ではレベル 2 で選られた各対象海域の全魚種（10 種）の值を加算したものを示した。表一 4 には具体的な適用例を示しているが、この事例では、外 海沿岸域の評価値が 7.71 で、人工漁礁域が 45.29 と約 6 倍ほど評価值が高い結果となった。この值 を影響緩和策の計画等に反映させることとなる。

表一4 BESTによる評価例

レベル 1

\begin{tabular}{|c|c|c|c|c|c|c|}
\hline \multirow[t]{2}{*}{$\begin{array}{ll}\text { 魚 種 } \\
\end{array}$} & \multirow[t]{2}{*}{ 対象海域 } & \multicolumn{2}{|c|}{ 成 魚 } & \multicolumn{2}{|c|}{ 稚仔魚 } & \multirow[t]{2}{*}{ 産卵量 } \\
\hline & & 飭生物量 & 既存量 & 飭生物量 & 現存量 & \\
\hline Atherionops affinis & 外海沿岸域 & 18.75 & 0.01 & 15.67 & 0.00 & 0.00 \\
\hline Oxyjul is cáliforniaca & 人工漁礁域 & 1475 & 0.77 & 15.67 & 11.99 & 0.00 \\
\hline
\end{tabular}

注）単位 餌生物 $: \mathrm{g} / \mathrm{m}^{2}$ 既存量 : 個㒄数 $/ 100 \mathrm{~m}^{2}$

レベル 2

\begin{tabular}{|c|c|c|c|c|c|c|c|}
\hline \multirow{2}{*}{ 魚 種 } & \multirow[t]{2}{*}{ 対象海域 } & \multicolumn{2}{|c|}{ 成 魚 } & \multicolumn{2}{|c|}{ 稚仔魚 } & \multirow[t]{2}{*}{ 産卵量 } & \multirow[t]{2}{*}{ 生産量 } \\
\hline & & 飭生物量 & 既存量 & 飭生物量 & 現存量 & & \\
\hline $\begin{array}{c}\text { Atherionops affinis } \\
\text {. }\end{array}$ & 外海沿岸域 & 0.01 & 0.02 & 0.00 & 0.00 & 0.00 & 0.03 \\
\hline Oxyjul is cal iforniaca & 人工漁礁域 & 0.99 & 0.98 & 1.00 & 1.00 & 0.00 & 3.39 \\
\hline
\end{tabular}

レベル 3

\begin{tabular}{|c|c|c|c|c|c|c|c|}
\hline \multirow[t]{2}{*}{ 対象海域 } & \multicolumn{2}{|c|}{ 成 魚 } & \multicolumn{2}{|c|}{ 稚仔魚 } & \multirow{2}{*}{$\begin{array}{c}\text { 産卵量 } \\
\text { 合計 }\end{array}$} & \multirow{2}{*}{$\begin{array}{c}\text { 生産量 } \\
\text { 合計 }\end{array}$} & \multirow[t]{2}{*}{ 合計 } \\
\hline & 飭生物量 & 既存量 & 飭生物量 & 現存量 & & & \\
\hline 外海沿岸域 & 2.39 & 2.20 & 1.85 & 0.25 & 0.00 & 1.01 & 7.71 \\
\hline 人工漁礁域 & 7.61 & 7.80 & 7.15 & 8.75 & 5.00 & 8.99 & 45.29 \\
\hline
\end{tabular}

3. 日本沿岸域への適用について

アメリカで開発された湿地帯などの機能評価手法は、湿地帯が持つ多くの機能をより科学的な根拠に基づいて 評価すること、評価の客観性の向上と簡易性を考慮した手順を持つこと、実際のプロジェクトにも採用された実 績があること、などから判断して有効な方法と考えられる。しかし、機能の種類や評価要素などを吟味すると、 内容的にはそのまま日本の水域での環境評価への適用性が難しいと考えられる点も多くある。たとえば、比較的 実用度の高いとされる HEP や WET、最新の評価法である HGM などは対象が湿地帯である。アメリカでは、多くの 湿地带ぶ内陸部に存在するはか、沿岸部であってもマングローブ等の植物が繁茂しているところが多く、日本で 一般に見られる干潟とは、地形・植生・生息生物などの重要な特性が異なると思われる。WETや HGM の枠組みを 参考に、日本の沿岸域の特性を考慮した手法に改良していく必要があると思われる。

一方、上記評価技術のなかで、内容的にも、日本沿岸域における開発での適用が好ましいと考えられる評価手 法の一つとして、適用場所や客観的な評価などの観点から前述の BEST があげられる。しかしながら、BESTでも、 影響対象生物（魚種）10 種を影響程度に応じて増減させたり、魚種以外の生物を追加したり、評価基準間に優先 順位を取り入れるなど、改善すべきである。特に、対象生物の選定は、対象海域の生態系で重要な役割を果たす キーストーン種を中心に考えるべきであり、全国沿岸域のキーストーン種あるいはそれに準じた種を選定する必 要がある。また、これら生物の成長および成長過程、食物連鎖、再生産等のデータベース化を充実させることが この評価手法の発展にとって重要であると考えられる。

日本でも独自に幾つかの評価手法が開発提案されている。全体的な立場から開発事業を評価する方法として、 沿岸域が求められる自然、防災、利用の 3 要素から海岸域を評価する三村らの評価法がある。この評価法は、沿 岸域の特性把握を念頭に、広範囲な海岸線に沿ってその特性を自然科学・経済活動・行政施策などによって定量 評価し、沿岸域を分類するものである。茨城県沿岸域を市町村単位に分け、それぞれの単位に対して、陸域の環 
境・海域の環境・人為的圧力・自然の外力などの指標毎に定量評価し、その分布を示した例が報告されている（三 村ら,1993）。このように、この手法は、広範囲な領域を関連諸特性によってゾーニングすることに、特に有効な 手段である。環境影響を受ける限られた領域にこの手法を適用して、その領域の環境価値を評価するには、評価 指標を絞り込むと同時にその構成要素を増やし局所的に詳細な評価を行うような修正が必要と思われる。たとえ ば、海域の環境について、水質・干潟・藻場を構成要素としているが、さらに、流況・魚類・底質状況などの項 目を追加することが望ましいと考えられる。漁場環境アセスメントの立場からは、漁場環境容量という考えをべ 一スに生物的評価手法がいくつか提案されている。例えば、構造モデル法や生活史モデル法などがあるが、これ らはモデルが複雑であり、かつ膨大なデータを必要とするなど実用化しにくい点がある。

このように、日本の沿岸域での環境評価を、実用的に満足できるレべルで、直ちに実施する評価法はないのが 現状であろう。一つの選択肢として、多くの機能評価を網羅し、なおかつ実用的なアメリカの評価手法に、日本 独自の評価方法の長所や日本の干潟等が持つ特性を考慮するなどした改良版を開発することが考えられる。

\section{3. 結論}

（1）アメリカで開発された各評価手法はそれぞれ適用範囲が異なり、対象とする地域の場所・その場所の持つ 機能・生息する生物種により、評価手法を選択する必要がある。

（2）アメリカで開発された湿地帯などの機能評価手法は、対象とする機能やその解析が科学的であること、比較的簡易な実用 的な手法であることなどから優れた方法と考えられる。しかし、機能の種類や評価要素などは日本の水域での特性と異な る点もあり、対象地域の水理的・地形的・生物的特性に合致した改良を施すことが望ましい。

（３）海上空港や港内埋立などにより失われる生息地の環境評価には、BRAT や BEST などの評価手法が有力であ る。

\section{附記}

この論文で報告する内容は、昨年、日本海洋開発建設協会がアメリカ陸軍工兵隊水路実験所 (WES)や環境修復事業 実施機関を訪問し、上記要素技術についての調査を行った結果に基づいた内容である。情報を与えていただいた WES 環境研究所の Theriot 博士はじめ専門家の方々、サンフランシスコ州立大学 Jossel yn 教授と調査団を指導し ていただいた Tekmarine 社 Sonu 博士に深く感謝いたします。

\section{参考文献}

（社）日本水産資源保護協会 漁場環境容量策定手法の検討、pp675 831, 924 927, 1975.

新保裕美，阪東浩造，田中昌宏（1997）：WETを用いた干潟域の機能と価値の評価，第52 回年講，（印刷中）.

三村信男, 関和美, 古米弘明 (1993)：環境特性の指標化と沿岸域の特性評価に関する研究, 海岸工学論文集, 第 40 巻, pp. 1041-1045.

Adanus, P.R., E. J. Clairain, R.D. Smith and R.E. Young (1987): Wet land Evaluation Technique (WET), Vol. II, US Army Corps of Engineers.

Bowen, M. and M. Small (1992): Ident ification and Evaluation of Coastal Habitat Evaluation Methodologies, US Army Corps of Engineers, Technical Report EL-92-21.

Brinson, M.M., F.R. Hauer, L.C. Lee, W.L. Nutter, R.D. Rheinhardt, R.D. Smith and D. Whigham (1995): A Guidebook for Appl icat ion of Hydrogeomorphic Assessments to River ine Wet lands, US Army Corps of Eng ineers, WRP-DE-11.

Clarke, D.G. and T. Miller-Way (1992):An Environmental Assessment of the Effects of Open-Water Disposal of Maintenance Dredged Material on Benthic Resources in Mobile Bay, Alabama, Miscel. Paper D-92-1, US Army Engineer Waterways Experiment Station.

Environmental Law Institute (1994): National Wetland Mitigation Banking Study, Institute for Water Resources Support Center, US Army Corps of Engineers, IWR Report 94-WMB-6.

Lunz, J.D. and D.R. Kendall (1982): Benthic Resources Assessment Technique, A Method for Quant ifying the Effects of Benthic Community Changes on Fish Resources, Oceans, September, pp.1021-1027.

MEC Analytical Systems, Inc. (1991): Production and Valuation Study of an Artificial Reef off Southern California. Prepared for Port of Long Beach, Port of Los Angeles, National Marine Fisheries Service. 